\title{
On China's Economic New Normal and Risk Prevention Measures of Real Estate Market
}

\author{
Chunli Wang \\ Chongqing Real Estate College, Chongqing, 401331, China
}

Keywords: Real estate market, Economic New Normal, Market risk, Overstock, Regulation prevention thought.

\begin{abstract}
At present, China's economy has formally entered the economic New Normal. One of subjects of China's national economy - real estate market also enters the new normal. Under the new normal, development and investment speed of Chinese real estate market, trading volume of real estate and real estate price present the rising trend. From regional level, if the stock of real estate market is larger, its market segmentation degree will be more intense. In combination of economic new normal background, this paper discusses internal and external risk factors of Chinese urban real estate market and gives risk prevention regulation thought based on urban real estate market under risk disposal background.
\end{abstract}

\section{Introduction}

New normal originated from US, while economic new normal is a new theory of socialism with Chinese characteristics proposed by Xi Jinping in 2014. In his opinion, China is now in the important stage of economic development, so national economic development must cater to the new period and new normal so as to seek a more stable and smooth development state. For China, economic new normal means China has been ready to enter the next new development stage, and achieve effective regulation of economic growth rate in the new stage.

\section{About China's economic new normal}

\subsection{Basic connotation of China's economic New Normal}

In China, on the one hand, economic new normal hopes the growth rate of national economy can slow down; on the other hand, it hopes to improve scientific and technological development level based on the development prospect of economic entity, overall narrow the gap between urban and rural areas and create conditions for residents to live a happy life. Besides, it hopes China's economy and even comprehensive field development should be brave to innovate and good at innovation. In this way, steady growth requirement of economy can be met under new normal background.

\subsection{Basic features of China's economic New Normal}

Basic features of China's economic new normal are under adjustment and optimization. There are mainly 3 points.

Firstly, economic growth rate slows down under China's economic new normal background, which is also one of important features of China's economic development trend mentioned above. Due to the impact of American subprime mortgage crisis in 2008, China suffered a serious blow at the economic level. This blow made domestic economic development field gradually realize economic growth could not be blind and too fast, and proper regulation is needed. After 2014, China formally proposed the concept of economic new normal. It hopes to respond to government call, and overall slowdown economic growth. In the past 4 years, China's economic growth rate was controlled at about 75 on the average, and the speed was controlled very well, basically met change features of national macroeconomic environment and comprehensively safeguarded stable development of 
peoples' interests.

Secondly, the huge change happens to industrial structure under economic new normal. For example, the industrial structure changes to medium and high-end level from medium and low-end level. It redefines the market. After many industries reach the saturation state, the problem of excess production capacity becomes a topic of the industry. Under economic new normal background, China is continuously developing new industries. Objectively speaking, real estate enterprise belongs to the new industry. It is the resource ignored by people. Under economic new normal, the improvement of economic development level and optimization of technology also make the new industry chain - real estate explored more deeply.

Thirdly, industrial resource allocation mode under economic new normal is changed thoroughly. It provides safeguard mechanism for economic new normal. The decisive change is proposed by combining the fundamental function of market, just as "guarantee the market to play a decisive role in resource allocation" proposed by the Third Plenary Session of the $18^{\text {th }}$ Central Committee of Communist Party of China. The government sector will properly loose the policy under the background of economic new normal, transform the functions, expand the market for resource allocation, conduct self-regulation around the new economic entity and form regular and relatively stable market environment.

\section{Risk features and risk factors of real estate market under China's economic New Normal background}

\subsection{Risk features of real estate market}

Under the background of China's economic new normal, the risks of real estate market present the diversification feature. For example, the prominent features such as too large stock of real estate projects, too fast price rise and irrational structure in most regions of China. All these can trigger real estate market risks. The severe housing overstock risk in current real estate market is an example. According to relevant data statistics issued by State Statistics Bureau, nationwide real estate area to be sold was 755 million $\mathrm{m}^{2}$ as of the end of 2017, down 17.50 million $\mathrm{m}^{2}$ compared with 2016. The decline degree of this index is at a high level from the perspective of absolute scale. Based on real estate market sale speed in the past 5 years, it will take about 5 years to completely digest the 17.50 million $\mathrm{m}^{2}$ area. This may cause the failure of market structure balance, finally leading to too stock pressure of real estate projects.

Besides, severe bubbles exist in housing price. At present, housing price adjustment of real estate market is based on macro-control policy of central government, but reflects the flexibility and variability in terms of economic growth and employment stability. In different regions, growth rate of real estate price also differs, but tends to the rising trend on the whole. In such background, about 80 large and medium cities in China present the rising trend in the aspect of housing sale price compared with the last statistical period, and the number of cities where housing price increases is still on the rise. Housing price bubble risk brought by this current situation is very severe. Even the third-tier cities keep the rising tendency of $4.28 \%$ annually on the average. The consequence of house buyers intensively entering the market and sharp growth of housing price in multiple cities leads to high leverage ratio. The pressure of housing price rise triggers price bubble which will directly result in a series of systematic risks triggered by too fast growth of real estate price.

Moreover, real estate capital chain risk, housing policy and urban environmental risk are important features in real estate market risk system. The industry and government should combine internal and external system risk factors to carry out more in-depth analysis.

\subsection{Risk factors of real estate market}

Based on the risk features of real estate market, market risk factors should be classified into internal risk factors and external risk factors.

Firstly, the representative of internal risk factors is real estate stock risk. It represents the digestion 
capacity of current commercial residential buildings and housing. If local area to be sold is more, this means local social effective demand may have presented the saturation state. Transaction growth rate of local housing may decline. The brand index factors represented by it also includes per-capita stock, digestion cycle and per-capita living area.

Secondly, external risk factors. China's real estate market will suffer external risk factors such as real estate fund risk, housing policy and environment. In the aspect of real estate fund risk, it is closely related to enterprise fund chain. If environmental change of real estate market leads to capital chain break, a series of risks will be caused in real estate development process. For instance, development investment growth rate of real estate enterprises will rise, and actual funds available will decrease. Meanwhile, it will influence fund self-raising capacity, enterprise loan interest rate and debt ratio of real estate enterprises. To a certain degree, capital chain of real estate enterprises cannot be broken, because it will harm benign operation of economic policy of real estate enterprises to a great degree. Seeing from housing policy and environmental risk, land macro-control policy, financial policy, urban infrastructure construction policy, urban public service level policy and urban permanent resident population will influence enterprises, then leading to market risks.

In conclusion, risk features and factors of real estate market are quite complex and diversified under China's economic new normal. They largely influence the be nigh and orderly development of real estate market ${ }^{[1]}$.

\section{Risk regulation and prevention thought of real estate market under China's economic New Normal}

Under China's economic new normal, risk prevention and handling must be reached during risk regulation and prevention of real estate market.

\subsection{Study on acting path based on risk prevention level}

Firstly, the acting path of urban real estate risks should be combined to study market risk prevention method for the sake of effective implementation of risk regulation work. In current real estate market, price risk, stock risk, capital risk and policy environment risk are of great influence. Real estate enterprises should propose prevention strategy based on the relation among multiple risks.

Secondly, it is required to speed up digestion stock and avoid stock risk. Stock risk is mainly reflected in the supply area, selling area and per-capital stock area of commercial residential buildings. Stock risk is the source of real estate market risks, and should be controlled effectively. The correct practice is to reduce stock area, and properly increase rigid demand sale area of commercial residential buildings. Real estate enterprises may overall and effectively activate housing lease market, and carry out special activities by combining social professional enterprises and property service enterprises, such as leasing management of social idle housing and encouraging residents to lease houses so as to cater to government's preferential tax policy. The government should strongly support investors to hold and manage their houses for leasing for a long time and encourage real estate enterprises to newly build and operate the houses for leasing ${ }^{[2]}$.

\subsection{Study on acting path based on risk disposal level}

The acting path based on risk disposal level should first guide housing consumption and overall handle real estate stock risk. Currently, the cities with large real estate stock pressure concentrate in the second-tiger, third-tiger and fourth-tier cities and the western area. They may trigger market risk due to too large stock. So, local government must rationally guide consumption and effectively digest the real estate stock. To be specific, the government should encourage local residents and especially peasants to purchase houses near the towns, and offer supporting financial services, such as housing loan and zero down payment. Besides, large quantities of housing demands can be released through renovation of shanty towns. Monetization settlement proportion for renovation of shanty towns may increase properly (70\% and above in a short time) to accelerate the speed of housing sale. For the cities with large real estate stock, the transformation force of shanty town renovation area should 
speed up properly.

Furthermore, it is required to improve financial policy and effectively increase the proportion of minimum down payment for the loan for purchasing houses, and the loan interest rate. If necessary, loan stop may be conducted directly. This method can effectively restrain speculation in housing market. Seeing from the perspective of financial bonds issued by banks, it is required to actively conduct mortgage-backed securitization in towns and cities, strongly support urban residents to purchase the first general commercial house, enhance bank loan risk prevention and create the favorable loan environment. The government should check land resource directory and avoid banks to grant land reservation loan for land reservation organizations except the land resource directory. Thus, financial departments of banks need to establish a set of relatively sound real estate financing information sharing mechanism, carry out multi-channel and uniform supervision of financing for listing, trust-based financial management, bank loan and private lending and improve real estate market environment under the background of China's economic new normal ${ }^{[3]}$.

\section{Summary}

To sum up, there are many real estate market risks under the background of China's economic new normal. So, short-term regulation and long-acting policy mechanism must be combined to achieve stabilization and optimization of real estate market, to realize optimal combination of policy system and behaviors, establish a risk prevention mechanism for the market and standardize all subject behaviors existing in real estate market.

\section{References}

[1] Wu Junmin, Wang Beiwen, Financial Warning Analysis for Listed Real Estate Companies under New Normal, Accountant, 2016(15):78-79.

[2] Zhong Ronggui, Jiang Li, China's Economic New Normal and Real Estate Risk Prevention, Modern Management Science, 2017(4):103-105.

[3] Zhang Qiwu, Study on Strategies to Promote Healthy Development of Real Estate Industry under New Normal, Construction Economics, 2015(5):22-26. 